\title{
Taxonomic Relations between Archaebacteria Including 6 Novel Genera Examined by Cross Hybridization of DNAs and $16 \mathrm{~S}$ rRNAs
}

Jenn Tu, David Prangishvilli, Harald Huber, Gertrud Wildgruber, Wolfram Zillig, and K.O. Stetter

Max-Planck-Institut für Biochemie, D-8033 Martinsried bei München, Federal Republic of Germany

Summary. DNAs from 16 species of archaebacteria including 6 novel isolates were hybridized with $16 \mathrm{~S}$ rRNAs from 7 species representing different orders or groups of the urkingdom of archaebacteria.

The yields, normalized for the number of genes per $\mu \mathrm{g}$ of DNA, and the temperature stabilities of all hybrids were determined and related to each other.

A taxonomic tree constructed from such fractional stability data reveals the same major divisions as that derived from comparative cataloging of $16 \mathrm{~S}$ rRNA sequences. The extreme halophiles appear however as a distinct order besides the three known divisions of methanogens.

The methanogens, the halophiles and Thermoplasma form one of two clearly recognizable branches of the archaebacterial urkingdom. The order represented by Sulfolobus and the related novel order Thermoproteales form the other branch.

Three novel genera, Thermoproteus, Desulfurococcus and the "stiff filaments" represent three families of this order.

The extremely thermophilic methanogen Methanothermus fervidus belongs to the Methanobacteriales. SN1, a methanogen from Italy, appears as another species of the genus Methanococcus. Another novel methanogen, M3, represents a genus or family of the order Methanomicrobiales.

Key words: Archaebacteria - Taxonomy - Evolution DNA - 16S rRNA - Hybridization - Phylogeny Thermoproteales
Introduction

Three novel extremely themophilic, anaerobic, sulfur respiring types of organisms isolated from Icelandic Solfataras, represented by 1 . the genus Thermoproteus, 2. the related "stiff filaments" (both Zillig et al. 1981a) and 3. the genus Desulfurococcus (Zillig et al. 1981b), have been recognized as archaebacteria (Woese et al. 1978; Fox et. al. 1980). The component patterns of the DNA dependent RNA polymerases of Thermoproteus and Desulfurococcus (Zillig et al. 1981c) and the comparison of the T1-RNAase oligonucleotide catalogs of the 16S rRNAs (Fox et al. 1977) from Thermoproteus and Sulfolobus (E. Stackebrandt, C.R. Woese and W. Zillig, unpublished) yield evidence for a relation between the novel thermoacidophiles and Sulfolobus (Brock et al. 1972) though their exact taxonomic position within the urkingdom of the archaebacteria and their relation with each other remain to be examined.

As indicated by the nature of its envelope and by its T1-RNAase oligonucleotide catalog, the extremely thermophilic methanogen Methanothermus fervidus, also isolated from an Icelandic hot spring (Stetter et al. 1981) is related to Methanobacterium. Its DNA dependent RNA polymerase shows however no immunochemical cross reaction with an antibody against the enzyme from Methanobacterium. Therefore, an independent determination of the phylogenetic distance between Methanothermus and Methanobacterium appeared instructive.

The taxonomic positions of two novel methanogens, SN1 and M3, isolated from Italian sources are yet undetermined.

The method applied in establishing the urkingdom of the archaebacteria, comparative cataloging of $16 \mathrm{~S}$ rRNA sequences (Fox et al. 1977), would require the determination of 6 new oligonucleotide catalogues. 
Table 1. List of the species of archaebacteria from which DNAs and RNAs $\left(^{+}\right)$were obtained, their sources and culture conditions, and the buffers and lysis procedures used in the preparation of nucleic acids

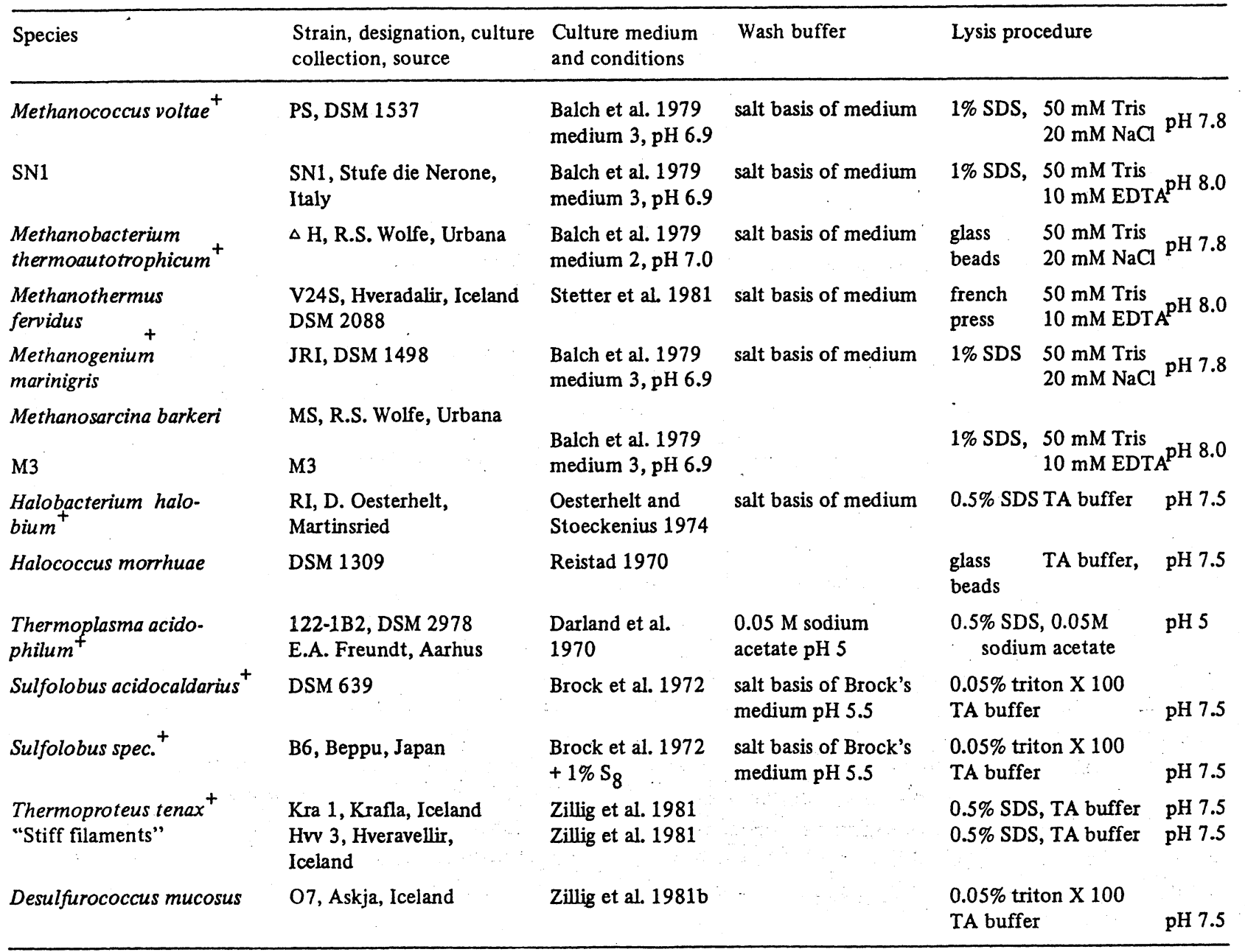

A fast and relatively simple procedure for the determination of phylogenetic distances, based on cross hybridization of labelled 16S rRNAs with filter bound DNAs has been described by De Ley and De Smedt (1975).

In this paper a phylogenetic tree of the archaebacteria containing all above mentioned novel genera is derived from cross hybridization data. On this basis the taxonomic positions of the three novel sulfur respiring types of thermophiles and the three new methanogens have been elucidated. The significance of the differences of this tree from that based on comparative cataloging data shall be discussed.

\section{Materials and Methods}

\section{Organisms}

The strain designations, culture collection designations and/or sources of all organisms, from which DNAs and 16S rRNAs have been prepared, and the media used for mass cultures are listed in Table 1.

\section{Preparation of DNAs}

5 to $10 \mathrm{~g}$ of bacterial mass (wet weight) were suspended in 25 to $50 \mathrm{ml}$ of the buffers listed in column 5 of Table 1 and lysed as indicated there. TA buffer is $0.05 \mathrm{M}$ tris $\mathrm{HCl}, 0.01 \mathrm{M}$ EDTA; $0.01 \mathrm{M} \beta$ mercaptoethanol, $0.022 \mathrm{M} \mathrm{NH}_{4} \mathrm{Cl} \mathrm{pH} \mathrm{7.5.}$

The DNA was prepared from the crude extracts by a phenol procedure as described previously (Zillig et al. 1980). All DNAs were banded by $\mathrm{CsCl}$ equilibrium gradient centrifugation.

\section{Preparation of $16 S \mathrm{rRNAs}$}

For the preparation of ${ }^{32} \mathrm{P}$ labelled 16S rRNAs, 20 to $160 \mathrm{ml}$ cultures of the 8 organisms marked with a star in column 1 of Table 1 were grown in the media listed in column 3 of Table 1 except that normal yeast extract was replaced by low phosphate yeast extract containing 20 nmoles phosphate per $g$. The latter was prepared by precipitation of phosphate with a slight excess of magnesium sulfate at $\mathrm{pH} 10.5$. If required the final phosphate concentration was adjusted to $2 \times 10^{-5} \mathrm{M}$ by addition of free phosphate. $25 \mu \mathrm{C}$ per $\mathrm{ml}$ of carrier free orthophosphate (New England Nuclear or Amersham Buchler, Braunschweig) were added after inoculation of the medium. Cells were harvested in the late exponential or the stationary phase of growth about 2 to 3 days after inoculation by 15 minutes centrifugation at 
Table 2. Temperatures of half melting $(=\mathrm{TMs}), \mathrm{cpm} / \mu \mathrm{g}$ DNA and correction factors for the calculation of fractional yields from these of all hybrids of 14 DNAs with $716 \mathrm{~S}$ rRNAs of different archaebacteria. The values in brackets in the Sulfolobus column are for the annealing of the DNA from Sulfolobus acidocaldarius DSM 639 with the homologuous RNA

\begin{tabular}{|c|c|c|c|c|c|c|c|c|c|c|c|c|c|c|c|}
\hline \multirow{2}{*}{$\begin{array}{l}\text { RNA from } \\
\text { DNA from }\end{array}$} & \multicolumn{2}{|c|}{ Methanococcus } & \multicolumn{2}{|c|}{ Methanobacterium } & \multicolumn{2}{|c|}{ Methanogenium } & \multicolumn{2}{|c|}{ Halobacterium } & \multicolumn{2}{|c|}{ Thermoplasma } & \multicolumn{2}{|c|}{ Sulfolobus B6 } & \multicolumn{2}{|c|}{ Thermoproteus } & \multirow[t]{2}{*}{$\begin{array}{l}\text { Divisions for } \\
\text { calculation } \\
\text { of fractional } \\
\text { yields }\end{array}$} \\
\hline & $\mathrm{TM}^{\circ} \mathrm{C}$ & $\begin{array}{l}\mathrm{cpm} / \mu \mathrm{g} \\
\mathrm{DNA}\end{array}$ & $\mathrm{TM}^{\circ} \mathrm{C}$ & $\begin{array}{l}\mathrm{cpm} / \mu \mathrm{g} \\
\mathrm{DNA}\end{array}$ & $\mathrm{TM}^{\circ} \mathrm{C}$ & $\begin{array}{l}\mathrm{cpm} / \mu \mathrm{g} \\
\mathrm{DNA}\end{array}$ & $\mathrm{TM}^{\circ} \mathrm{C}$ & $\begin{array}{l}\mathrm{cpm} / \mu \mathrm{g} \\
\mathrm{DNA}\end{array}$ & $\mathrm{TM}^{\circ} \mathrm{C}$ & $\begin{array}{l}\mathrm{cpm} / \mu \mathrm{g} \\
\text { DNA }\end{array}$ & $\mathrm{TM}^{\circ} \mathrm{C}$ & $\begin{array}{l}\mathrm{cpm} / \mu \mathrm{g} \\
\text { DNA }\end{array}$ & $\mathrm{TM}^{\circ} \mathrm{C}$ & $\begin{array}{l}\mathrm{cpm} / \mu \mathrm{g} \\
\mathrm{DNA}\end{array}$ & \\
\hline $\begin{array}{l}\text { Methanococcus } \\
\text { SN1 }\end{array}$ & $\begin{array}{l}78.2 \\
77.1\end{array}$ & $\begin{array}{r}1015 \\
276\end{array}$ & $\begin{array}{l}73.1 \\
75.8\end{array}$ & $\begin{array}{l}50 \\
57\end{array}$ & $\begin{array}{l}71.7 \\
69.7\end{array}$ & $\begin{array}{l}60 \\
37\end{array}$ & $\begin{array}{l}67.1 \\
68.4\end{array}$ & $\begin{array}{l}354 \\
239\end{array}$ & $\begin{array}{l}67.6 \\
67.6\end{array}$ & $\begin{array}{l}254 \\
156\end{array}$ & $\begin{array}{l}71.7 \\
71.9\end{array}$ & $\begin{array}{l}36 \\
38\end{array}$ & $\begin{array}{l}72.5 \\
72.5\end{array}$ & $\begin{array}{l}26 \\
20\end{array}$ & $\begin{array}{r}1015 \\
677\end{array}$ \\
\hline $\begin{array}{l}\text { Methanobacterium } \\
\text { Methanothermus }\end{array}$ & $\begin{array}{l}71.8 \\
72.3\end{array}$ & $\begin{array}{l}200 \\
250\end{array}$ & $\begin{array}{l}78.5 \\
75.4\end{array}$ & $\begin{array}{l}770 \\
212\end{array}$ & $\begin{array}{l}71.7 \\
70.4\end{array}$ & $\begin{array}{l}57 \\
69\end{array}$ & $\begin{array}{l}70.5 \\
70.8\end{array}$ & $\begin{array}{l}489 \\
462\end{array}$ & $\begin{array}{l}67.9 \\
69.8\end{array}$ & $\begin{array}{l}312 \\
450\end{array}$ & $\begin{array}{l}68.7 \\
72.6\end{array}$ & $\begin{array}{r}46 \\
101\end{array}$ & $\begin{array}{l}72.1 \\
72.1\end{array}$ & $\begin{array}{l}44 \\
80\end{array}$ & $\begin{array}{r}770 \\
1136\end{array}$ \\
\hline $\begin{array}{l}\text { Methanogenium } \\
\text { Methanosarcina } \\
\text { M3 }\end{array}$ & $\begin{array}{l}68.0 \\
68.3 \\
67.8\end{array}$ & $\begin{array}{r}28 \\
67 \\
120\end{array}$ & $\begin{array}{l}71.5 \\
70.8 \\
71.4\end{array}$ & $\begin{array}{l}13 \\
31 \\
45\end{array}$ & $\begin{array}{l}81.4 \\
73.3 \\
72.6\end{array}$ & $\begin{array}{r}292 \\
61 \\
60\end{array}$ & $\begin{array}{l}69.5 \\
70.6 \\
69.3\end{array}$ & $\begin{array}{l}120 \\
278 \\
593\end{array}$ & $\begin{array}{l}71.1 \\
68.7 \\
-\end{array}$ & $\begin{array}{r}59 \\
177 \\
-\end{array}$ & $\begin{array}{l}64.6 \\
64.5 \\
-\end{array}$ & $\begin{array}{l}27 \\
41 \\
-\end{array}$ & $\begin{array}{l}68.4 \\
69.6 \\
-\end{array}$ & $\begin{array}{l}15 \\
19 \\
-\end{array}$ & $\begin{array}{r}292 \\
573 \\
1217\end{array}$ \\
\hline $\begin{array}{l}\text { Halobacterium } \\
\text { Halococcus }\end{array}$ & $\begin{array}{l}67.1 \\
67.5\end{array}$ & $\begin{array}{l}41 \\
31\end{array}$ & $\begin{array}{l}70.0 \\
70.6\end{array}$ & $\begin{array}{l}14 \\
12\end{array}$ & $\begin{array}{l}71.5 \\
68.5\end{array}$ & $\begin{array}{l}25 \\
17\end{array}$ & $\begin{array}{l}85.1 \\
75.8\end{array}$ & $\begin{array}{r}1015 \\
516\end{array}$ & $\begin{array}{l}66.0 \\
67.0\end{array}$ & $\begin{array}{r}109 \\
61\end{array}$ & $\begin{array}{l}68.7 \\
67.6\end{array}$ & $\begin{array}{r}12 \\
9\end{array}$ & $\begin{array}{l}67.0 \\
67.5\end{array}$ & $\begin{array}{l}17 \\
14\end{array}$ & $\begin{array}{l}1015 \\
1015\end{array}$ \\
\hline Thermoplasma & 68.5 & 58 & 69.8 & 15 & 67.6 & 18 & 66.1 & 163 & 81.1 & 2038 & 67.9 & 41 & 65.6 & 18 & 2038 \\
\hline Sulfolobus (DSM 639) & 68.4 & 40 & 67.4 & 11 & 64.8 & 16 & 67.1 & 80 & 67.4 & 104 & $\begin{array}{c}81.7 \\
(86.0)\end{array}$ & 119 & $\begin{array}{r}73.7 \\
(334)\end{array}$ & 39 & 334 \\
\hline Thermoproteus & 67.1 & 39 & 69.7 & 9 & 67.0 & 18 & 68.4 & 83 & 67.4 & 108 & 72.0 & 75 & 87.5 & 220 & 220 \\
\hline "Stiff filaments" & -- & - & - & - & 72.4 & 40 & - & - & 68.4 & 178 & 75.2 & 166 & 78.2 & 261 & 440 \\
\hline Desulfurococcus & 66.0 & 74 & 68.9 & 12 & 66.6 & 23 & 68.1 & 109 & 67.2 & 128 & 74.6 & 65 & 74.2 & 108 & 301 \\
\hline
\end{tabular}

$5000 \mathrm{cpm}$ in a Heraeus-Christ minifuge and washed once with the buffers listed in column 4 of Table 1 . They were suspended in 1-2 $\mathrm{ml}$ of the buffers listed in column 5 of Table 1 and lysed as listed there. The lysates were shaken with 1 volume of phenol for 3 minutes. Then, 1 volume of chloroform was added, the mixtures were shaken for another 3 minutes and centrifuged for 5 minutes as above. The aqueous phases were reextracted twice with 2 volumes of chloroform. After addition of $10 \mu \mathrm{g}$ per $\mathrm{ml}$ of yeast sRNA (Boehringer) and $0.3 \mathrm{M}$ sodium acetate (final concentration) the nucleic acids were precipitated with 2 volumes of ethanol. After 16 hours at $-20^{\circ} \mathrm{C}$, they were pelleted in 30 minutes as above, washed once with cold absolute ethanol, dried and dissolved in water. They were separated by a modification of the acidic urea agarose gel electrophoresis procedure described by Rosen et al. (1975) and visualized by autoradiography.

The 16S rRNA bands were excised and eluted electrophoretically as described by Goldfarb and Daniel (1981). The $16 \mathrm{~S}$ IRNAs were precipitated from the eluates and then washed and dried as described above for the total nucleic acids. They were dissolved in $5 \mathrm{xSSC}$ containing $25 \%$ formamide.

\section{Hybridisation}

Hybridisations to 1 to 6 nitro-cellulose filters of $0.6 \mathrm{~cm}$ diameter carrying 2 to $9 \mu \mathrm{g}$ each of the different DNAs were performed in $200 \mu \mathrm{l}$ aliquots of $5 \mathrm{xSSC}$ containing $25 \%$ formamide and $166000 \mathrm{cpm}$ corresponding to $60 \mu \mathrm{g}$ of RNA per filter in $1 \mathrm{ml}$ Eppendorf tubes for 16 hours at $60^{\circ} \mathrm{C}$. In the case of hybridisation of Thermoplasma DNA with Thermoplasma rRNA this was found to be a saturating amount of RNA. The supernatant was then removed by centrifugation through holes pinched into the bottoms of the tubes. The filters were washed twice with $0.5 \mathrm{ml}$ each of $5 \mathrm{xSSC}$ and then subjected to digestion in $0.5 \mathrm{ml}$ each of a solution of $10 \mu \mathrm{g}$ RNAase A (Worthington) and 50 units RNAase $\mathrm{T} 1$ (Worthington) per $\mathrm{ml} 5 \mathrm{xSSC}$ for 45 minutes at $37^{\circ} \mathrm{C}$, and finally washed 2 times with $0.5 \mathrm{ml}$ each of $5 \times$ SSC. The digestion was repeated. The filters were suspended in $0.3 \mathrm{ml} 5 \mathrm{xSSC}$ containing $25 \%$ formamide. The filter bound radioactivity was determined as Cerenkov counts. It ranged between more than 70000 and a few hundred cpm.
The filters in $0.3 \mathrm{ml} 5 \times \mathrm{xSC}$ and $25 \%$ formamide were then heated successively to $65,70,75,80,85,90$ and $95^{\circ} \mathrm{C}$ for 15 minutes each. After each heating period, the buffer was replaced and the residual filter bound radioactivity was determined as Cerenkov counts.

Finally, the filter bound DNA was determined as described by Burton (1968).

\section{Results}

32 $\mathrm{P}$ labelled 16S rRNAs from members of 7 known or presumed orders of the archaebacterial urkingdom were hybridized with 14 different DNAs from archaebacteria, of which 6 were from the species of undetermined taxonomic position mentioned in the introduction. Two sets of data were determined, namely A) the cpm per $\mu \mathrm{g}$ of DNA hybridized in RNAase stable form at $60^{\circ} \mathrm{C}$ in $5 \mathrm{xSSC}$ containing $25 \%$ formamide and $\mathrm{B}$ ) the temperature stability curves for all hybrids (Table 2 ). The data of set $A$ which have been obtained in RNA excess, depend both on genome size and on the number of rRNA genes per genome. Without further information, it is not possible to determine both parameters separately. However, expression of the data as fractions of the yields of the hybridizations with the homologuous DNAs, which are taken to be 1 , related all values to each other and standardized them for the number of 16S rRNA genes (Table 3).

In the case of hybridizations with DNAs for which homologuous RNAs were not available, correction factors were determined empirically. The basis is the observation that the yield ratios of hybrids containing DNAs of different members of one order appear rather constant independent of the RNA probe as long as this is from a different order. 
Table 3. 1. Spans between the temperature of hybridization $\left(60^{\circ} \mathrm{C}\right)$ and the TMs of the hybrids expressed as fractions of the spans between $60^{\circ} \mathrm{C}$ and the TMs of the hybrids with the homologuous DNAs $(\equiv 1)$ ( = fractional stabilities, fr. st. $=\mathrm{TM}-60^{\circ} \mathrm{C} / \mathrm{TMhom},-60^{\circ} \mathrm{C}$ ), and 2 . yields of hybridization expressed as fractions of yields of the hybridization with the homologuous DNA. For calculation of data see Materials and Methods

\begin{tabular}{|c|c|c|c|c|c|c|c|c|c|c|c|c|c|c|}
\hline \multirow{2}{*}{$\frac{\text { RNA from }}{\text { DNA from }}$} & \multicolumn{2}{|c|}{ Methanococcus } & \multicolumn{2}{|c|}{ Methanobacterium } & \multicolumn{2}{|c|}{ Methanogenium } & \multicolumn{2}{|c|}{ Halobacterium } & \multicolumn{2}{|c|}{ Thermoplasma } & \multicolumn{2}{|c|}{ Sulfolobus B6 } & \multicolumn{2}{|c|}{ Thermoproteus } \\
\hline & fr. st. & yield & fr. st. & yield & fr. st. & yield & fr. st. & yield & fr. st. & yield & fr. st. & yield & fr. st. & yield \\
\hline Methanococcus & 1 & 1 & 0.71 & 0.05 & 0.55 & 0.06 & 0.28 & 0.35 & 0.36 & 0.25 & 0.45 & 0.04 & 0.24 & 0.03 \\
\hline SN1 & 0.94 & 0.4 & 0.85 & 0.08 & 0.45 & 0.05 & 0.33 & 0.35 & 0.36 & 0.23 & 0.46 & 0.05 & 0.24 & 0.03 \\
\hline Methanobacterium & 0.65 & 0.26 & 1 & 1 & 0.55 & 0.07 & 0.42 & 0.64 & 0.37 & 0.40 & 0.33 & 0.06 & 0.25 & 0.06 \\
\hline Methanothermus & 0.68 & 0.22 & 0.83 & 0.19 & 0.49 & 0.06 & 0.44 & 0.40 & 0.46 & 0.39 & 0.48 & 0.09 & 0.26 & 0.07 \\
\hline Methanogenium & 0.44 & 0.10 & 0.62 & 0.05 & 1 & 1 & 0.38 & 0.42 & 0.53 & 0.20 & 0.17 & 0.10 & 0.18 & 0.05 \\
\hline Methanosarcina & 0.46 & 0.12 & 0.58 & 0.05 & 0.62 & 0.11 & 0.42 & 0.50 & 0.41 & 0.31 & 0.17 & 0.07 & 0.19 & 0.03 \\
\hline M3 & 0.43 & 0.10 & 0.62 & 0.04 & 0.59 & 0.16 & 0.37 & 0.50 & - & - & -- & -- & 0.18 & 0.02 \\
\hline Halobacterium & 0.39 & 0.04 & 0.54 & 0.01 & 0.54 & 0.02 & 1 & 1 & 0.28 & 0.11 & 0.33 & 0.01 & 0.14 & 0.02 \\
\hline Halococcus & 0.41 & 0.03 & 0.57 & 0.01 & 0.40 & 0.02 & 0.63 & 0.51 & 0.38 & 0.06 & 0.29 & 0.01 & 0.14 & 0.01 \\
\hline Thermoplasma & 0.47 & 0.03 & 0.53 & 0.01 & 0.36 & 0.01 & 0.24 & 0.08 & 1 & 1 & 0.30 & 0.02 & 0.11 & 0.01 \\
\hline Sulfolobus (DSM 639) & 0.46 & 0.12 & 0.40 & 0.03 & 0.22 & 0.05 & 0.28 & 0.24 & 0.35 & 0.31 & $\begin{array}{c}0.83 \\
(1 .)^{\mathrm{a}}\end{array}$ & $\begin{array}{l}0.36 \\
(1 .)^{\mathrm{a}}\end{array}$ & 0.49 & 0.12 \\
\hline Thermoproteus & 0.39 & 0.18 & 0.52 & 0.04 & 0.33 & 0.08 & 0.33 & 0.38 & 0.35 & 0.49 & 0.46 & 0.34 & 1 & 1 \\
\hline "Stiff filaments" & - & - & - & - & 0.31 & 0.09 & - & - & 0.40 & 0.40 & 0.58 & 0.38 & 0.67 & 0.60 \\
\hline Desulfurococcus & 0.33 & 0.25 & 0.48 & 0.04 & - & 0.08 & 0.32 & 0.36 & 0.34 & 0.42 & 0.56 & 0.21 & 0.57 & 0.30 \\
\hline
\end{tabular}

${ }^{a}$ For RNA of Sulfolobus DSM 639 with DNA of Sulfolobus DSM 639

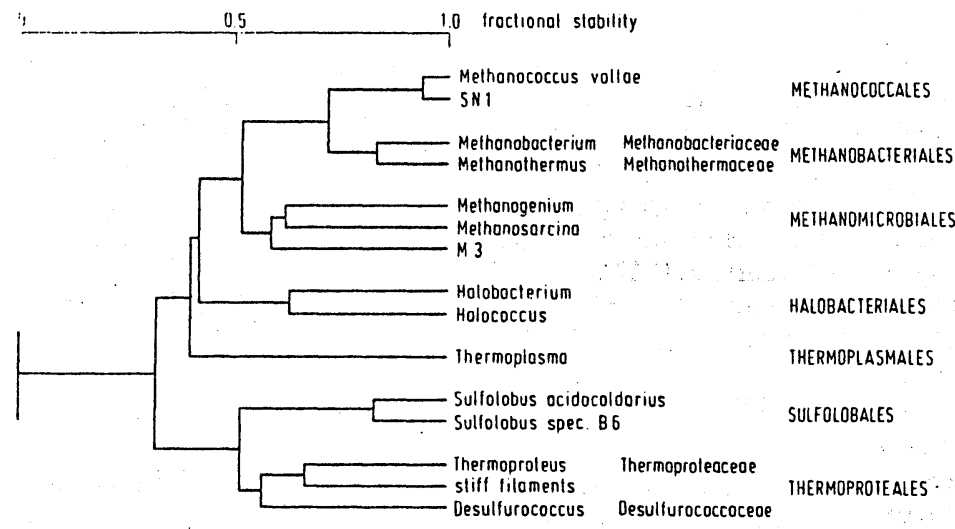

Fig. 1. Dendrogram of fractional stabilities of hybrids between 16S rRNAs and DNAs of archaebacteria. Construction of dendrogram from the values listed in Table 3 as described in Materials and Methods.
From the melting curves obtained from set $\mathrm{B}$ of the data temperatures of $50 \%$ stability of all hybrids, termed TMs, were determined. To relate them to each other, the spans between the temperature of hybridization, $60^{\circ} \mathrm{C}$, and the TMs of the homologuous pairings were taken to be 1 and the TMs of other hybrids containing the same RNA were expressed as fractions thereof. The figures obtained in this way, termed fractional stabilities (see Table 3) could be used in the same manner as the fractional yields or for example $S_{A B}$ values (Fox et al. 1977) for measuring distances between the species from which RNA and DNA had been obtained, thus allowing the construction of a dendrogram. It should, however, be pointed out that a linear relationship between the fractional stability and the phylogenetic distance or perturbation of homology cannot be assumed so that such a dendrogram expresses the order, but not the magnitudes of taxonomic relations.

None of the RNA probes representing different divisions of the archaebacterial kingdom yielded a stable hybrid with DNAs from E.coli, Saccharomyces cerevisiae and calf thymus.

The fractional yields listed in Table 3 are only in two RNA series, from Halobacterium and from Thermoplasma, in the same range as the fractional stabilities. The few high values in the other series are for pairings of the RNA with DNAs either of close relatives, e.g. Methanogenium-Methanosarcina, Sulfolobus acidocaldarius DSM 639-Sulfolobus B6, or of presumed close relatives, e.g. Methanobacterium-Methanothermus, or they may indicate closeness (see below), e.g. Methanococcus-SN1, Methanogenium-M3, Thermoproteus-stiff filaments-Desulfurococcus-Sulfolobus. The other values in these series are low but very similar for DNAs from related or presumably related organisms. The fractional yields of reciprocal pairings are often quite different. An explanation is offered in the discussion. The orders of the fractional yields in the different RNA series correspond to those of the fractional stabilities only for the highest values. 
The yield data could thus only be used as additional evidence for close relation and the quantitative evaluation was confined to the fractional stabilities. As the fractional yields, within a given RNA series, these agree closely for related or probably related organisms. As those, in a given RNA series, they are highest for the DNAs of organisms closely or probably closely related to the RNA donor. But, in addition, they are similar in reciprocal pairings.

Because intra order distances were normally measured in but one direction (with one RNA), the fractional stabilities of pairings of close relatives were immediately used as intra order branching levels.

Since the distances between different members of one order and different members of another order are very similar to each other (Table 3), inter order distances were determined by averaging all measured distances between members of the different orders including values for reciprocal pairings. The sequence of branching levels in constructing a dendrogram including all species studied, was determined by proceeding in the direction of decreasing relationship and averaging corresponding distances.

The significance of all intraorder branchings and of some interorder ramifications like those between the Methanococcales, the Methanobacteriales and the Methanomicrobiales, and that between the Thermoproteales and the order represented by Sulfolobus is strengthened by the fractional yield data. In addition, close correlations within groups are evident in all but the homologuous RNA series from the small divergence of both the fractional yields and the fractional stabilities of the hybrids containing DNAs of different members of a group.

The affiliation of a species to an order can just the reverse be immediately recognized in the corresponding RNA series from the deviation of the respective fractional yields and fractional stabilities from those measured in that series for members of all other orders. Furthermore, both values are considerably higher than those appertaining other organisms, and may approach 1 .

SN1 appears so close to Methanococcus voltae that it can be assumed to belong to the same genus. The distance of M3 to Methanogenium and Methanosarcina indicates that it represents at least another genus, if not another family of the order Methanomicrobiales. The distances between the different members of the order Thermoproteales is in the same range. We therefore consider them different families within this order. Desulfurococcus is less closely related to Thermoproteus than the stiff filaments.

\section{Discussion}

The method applied here for the determination of the taxonomic positions of several novel species of archae- bacteria has been developed by De Ley and De Smedt (1975). They have already pointed out that only the stabilities and not the yields of hybrids furnish reliable information for the determination of taxonomic relations. This is also clear from our data (Table 2), especially from the strong drop of the fractional yields with increasing phylogenetic distance and from the striking differences of reciprocal values. These observations could be explained by assuming that during hybridization, an equilibrium between hybridized RNA and free RNA with native secondary and tertiary structure is established which, among other parameters, depends on the stability of the secondary and tertiary structure of the particular rRNA in relation to that of the hybrid. The following formulation, in which ts means tertiary structure intact, ss means no tertiary structure, explains this model: RNAts + DNA $\underset{\leftarrow}{\mathrm{RNAss}}+$ DNA $\underset{\rightarrow}{\mathrm{RNAss}}$ - DNA. Many of the rRNAs used in these hybridization experiments, as for example those from the highly thermophilic organisms. Thermoproteus and Sulfolobus, should have quite stable tertiary structures under hybridization conditions. These show the described behaviour markedly. On the other hand, the fractional yields of hybrids containing the rRNA of Halobacterium, an organism growing around $40^{\circ} \mathrm{C}$ and with a DNA of high GC content, are in the same range as the corresponding fractional stabilities.

It must be emphasized that because of the lack of relevant theoretical background, the treatment of the data is entirely empirical. The approach used especially the normalisation to the span between the hybridization temperature and the TMs of the homologuous hybridization accounts for the large differences between the TMs of different homologuous pairings and allows to treat the data like $\mathrm{S}_{\mathrm{AB}}$ values.

Dendrograms have been constructed as well with weighted information as from all data available. The differences are small. The essential conclusions remain the same.

The appointment of species of unknown taxonomic position to orders on the basis of hybridization experiments is particularly significant because their intraorder hybrids have always a high fractional stability, are always obtained in high fractional yields and are related to different hybridization probes by yield and stability data very close to those of other members of that order.

The division of the urkingdom of the archaebacteria into two different branches, that of the methanogens and that of the thermoacidophiles, follows clearly from our data. The order of association, and even the association itself, of the extreme halophiles and particularly of Thermoplasma with the branch of the methanogens is less significant. Thermoplasma has a rather low relation with members of both branches and might thus even represent a third branch between the others.

In contrast to their position in the tree obtained by comparative cataloging of 16S RNA (Fox et al. 1980 ), in the dendrogram derived from the hybridiza- 
tion data the extreme halophiles appear as an order by themselves. Also, the Methanococcales and the Methanobacteriales appear to be closer to each other than either of them to the Methanomicrobiales. Such differences between dendrograms obtained in different ways ought to be expected, especially since the $\mathrm{S}_{\mathrm{AB}}$ method confines itself to the consideration of identities, though in a lucid way, whereas cross hybridization measures similarities as long as they suffice for hybridization. Though the division of orders or groups of similarly large distance follows from both dendrograms, the safe derivation of an evolutionary from a "taxonomic" tree has to await a more extensive comparison of archaebacteria. This is also indicated by the finding that in a tree based on 5S RNA sequence, the halophiles are closer to the Methanococcales than to Methanobacterium (G.E. Fox, personal communication).

Differences between the dendrograms derived from $\mathrm{S}_{\mathrm{AB}} \mathrm{S}$ and from hybridization experiments might also result from the treatment of the data. The fractional stabilities of inter-species hybrids depend on the degree of homology, supposedly proportional to phylogenetic relation, in an unknown, probably non-linear manner. Thus, the dendrogram of these values requires conversion to a tree of taxonomic distance after understanding of this relationship.

Intraorder distances appear too large in comparison with those between different orders which seem to approach an upper limit. This notion is in line with the observation that all fractional stabilities of hybrids of different DNAs or RNAs of one order with different RNAs or DNAs of another order are very close to each other though the fractional stabilities within the orders can be almost as small as those of interorder hybrids.

The establishment of a novel order, the Thermoproteales, specifically related to the order represented by Sulfolobus and forming a recognizable thermoacidophilic branch with it, is in line with observations on the component patterns of DNA dependent RNA polymerases (Zillig and Stetter 1980; Zillig et al. 1981c). It follows also from comparative cataloging of $16 \mathrm{~S}$ rRNA, which yields an $\mathrm{S}_{\mathrm{AB}}$ of 0.2 between Sulfolobus and Thermoproteus, significantly higher than the $\mathrm{S}_{\mathrm{AB}}$ of 0.17 between Sulfolobus and the rest of the archaebacteria (C.R. Woese, E. Stackebrandt and W. Zillig, unpublished). The Thermoproteales appear as the anaerobic counterpart of the aerobic, and therefore probably younger, "Sulfolobus", much like the anaerobic Methanogens are related to the aerobic extreme halophiles.

M3 is as distant from Methanogenium as Methanosarcina and thus represents another genus or even family of the Methanomicrobiales.

Methanothermus appears closer to Methanobacterium than expected from the absence of immunochemical cross reaction of their RNA polymerases and from $16 \mathrm{~S}$
rRNA cataloging (E. Stackebrandt, personal communication) which led to consider it as representative of a novel family of the Methanobacteriales. This could result from a high stability of the homologuous annealing product of this extremely thermophilic species. The given fractional stabilities could then appear too low because they were calculated with the relatively low TM of the auto annealing product of Methanobacterium.

For the purpose of this paper, the stability data were treated in a rather summary way. Different melting curves have however different slopes and shapes. Some are concave, some convex. Some, for example those of the hybrids between Sulfolobus rRNA and the DNAs of the three Thermoproteales, have two points of inflection (not shown), possibly indicating domains of differing conservatively, e.g. differing relation with the donor of the hybridization probe. A more detailed analysis of such observations could possibly help to specify the nature of the relations between different archaebacteria.

Acknowledgement. Thanks are due to the Deutsche Forschungsgemeinschaft, SFB 51, for generous support of this work, to Wolfgang Schulz for helpful discussions and to Ingelore Holz for excellent technical assistance.

\section{References}

Balch WE, Fox SE, Magrum LJ, Woese CR, Wolfe RS (1979) Microbiol Rev 13:260-296

Brock TD, Brock KM, Belley RT, Weiss RL (1972) Arch Microbiol 84:54-68

Burton K (1956) Biochem J 62:315-323

Fox GE, Pechman KR, Woese CR (1977) Int J Syst Bact 27: $44-57$

Fox GE, Stackebrandt E, Hespell RB, Gibson J, Maniloff J, Dyer TA, Wolfe RS, Balch WE, Tanner RS, Zablen LB, Blakemore R, Gupta R, Bonen L, Lewis BJ, Stahl DA, Luehrsen KR, Chen KN, Woese CR (1980) Science 209:457-463

Goldfarb A, Daniel V (1981) J Mol Biol 146:393-412

Ley J de, Smedt V de (1975) Antonie van Leeuwenhoek 41: 287-307

Rosen JM, Woo SLC, Holder JW, Means AR, O'Malley BW (1975) Biochemistry 14:69-78

Stetter KO, Thomm M, Winter J, Wildgruber G, Huber H, Zillig W, Janekovic D, König H, Palm P, Wunderl S (1981) Zbl Bakt Hyg Orig C2:166-178

Woese CR, Magrum LJ, Fox GE (1978) J Mol Evol 11:245-252

Zillig W, Stetter KO (1980) Univ of Tokyo Press. Elsevier, North Holland, Amsterdam-New York-Oxford, Osawa S, Ozeki H, Uchida H, Yura T (eds)

Zillig W, Stetter KO, Wunderl S, Schulz W, Priess H, Scholz I (1980) Arch Microbiol 125:259-269

Zillig W, Stetter KO, Schäfer W, Janekovic D, Wunderl S, Holz I, Palm P (1981a) Zbl Bakt Hyg I. Abt Orig C2, 205-227

Zillig W, Stetter KO, Prangishvilli D, Schäfer W, Wunderl S, Janekovic D, Holz I, Palm P (1981b) Zbl Bakt Hyg I. Abt Orig $\mathrm{C}$, in press

Zillig W, Tu J, Holz I (1981c) Nature 293:85-86

Received October 28, 1981/Accepted January 7, 1982 